\title{
Tantangan Pastoral Care bagi Transgender
}

\author{
Dwi Indarti Hutami Dewi \\ Wakil Ketua II Bidang Keuangan Sekolah Tinggi Teologi Excelsius \\ dwiindarti@sttexcelsius.ac.id
}

\begin{abstract}
The existence of transgender people in the community cannot be denied. Some of them also have achievements both nationally and internationally. Some transgender individuals have strong self-esteem that persist in the midst of a society where the majority ignore and even reject them. Others experience feelings of grief and even despair until suicide due to severe rejection especially from the family. The church as a family home that must love and protect each member of the congregation must not be favoritism. The church needs to reach out to transgender people through pastoral care. Counseling services also need to be opened for them so that mental recovery can occur.
\end{abstract}

Keywords: Transgender; Church; Pastoral Care

\begin{abstract}
Abstrak
Keberadaan orang transgender dalam komunitas tidak dapat disangkal. Beberapa dari mereka juga memiliki prestasi baik secara nasional maupun internasional. Beberapa individu transgender memiliki harga diri yang kuat yang bertahan di tengah-tengah masyarakat di mana mayoritas mengabaikan dan bahkan menolak mereka. Yang lain mengalami perasaan sedih dan bahkan putus asa sampai bunuh diri karena penolakan yang parah terutama dari keluarga. Gereja sebagai rumah keluarga yang harus mencintai dan melindungi setiap anggota jemaat tidak boleh pilih kasih. Gereja perlu menjangkau orangorang transgender melalui perawatan pastoral. Layanan konseling juga perlu dibuka untuk mereka sehingga pemulihan mental dapat terjadi.
\end{abstract}

Kata Kunci: Transgender; Gereja; Perawatan Pastoral 


\section{PENDAHULUAN}

Isu-isu transgender merupakan sesuatu yang dapat dikatakan baru dalam khazanah ilmu pengetahuan, khususnya bidang kesehatan. Bahkan istilah transgender itu dipopulerkan di tahun 1970-an, di mana istilah ini disematkan untuk menggambarkan seseorang yang mengganti identitas gendernya tanpa melakukan perubahan organ seksnya. Kemudian pada tahun 1980-an istilahini berkembang dan menjadi suatu alat pemersatu semua orang yang merasa identitas gendernya tidak cocok dengan identitas yang telah mereka dapat sejak kecil. $^{1}$

Pada era post-modern isu transgender menjadi pergumulan antara penggunaan ilmu psikoterapi dengan penggunaan teologi, khususnya teologi pastoral, di pihak lain. Pastoral gereja terancam untuk tidak setia lagi kepada doktrin atau aturan-aturan gereja Kristen, karena penyelesaian masalah pastoral selalu akan dikaitkan dengan konteks, bukan mencari benar atau salah, baik atau jahat, tetapi apakah penyembuhan itu cocok atau tidak cocok dengan konteksnya.

Beberapa tahun terakhir baik individu maupun komunitas transgender sudah secara terbuka menunjukkan keberadaan mereka di

${ }^{1}$ Safrudin Azis, Pendidikan Seks Perspektif Terapi Sufistik bagi LGBT (Kendal: Achmad Jaya Group, 2017), 54. tengah masyarakat. Mereka menginginkan pengakuan baik secara sosial dan religi bahwa Allah juga menciptakan mereka. Menurut "kaum" transgender, tidak ada alasan bagi masyarakat untuk menolak keberadaan mereka di muka bumi. Bahkan tidak ada alasan bagi agamawan untuk menghakimi mereka sebagai makhluk yang jatuh dalam dosa.

Setiap individu transgender pasti pernah mengalami fase di mana mereka merasa kebingungan mengenai identitas mereka. Pertanyaan-pertanyaan pribadi timbul dari individu tentang identitas seksual, termasuk orang-orang yang tidak yakin apakah mereka "benar-benar" laki-laki atau perempuan. Beberapa orang dari mereka sesekali atau secara rutin berpakaian dan menampilkan diri sebagai anggota dari lawan jenis, sedangkan yang lain mencoba terapi hormon atau melakukan prosedur bedah untuk mengubah identifikasi seks mereka dari laki-laki menjadi perempuan atau dari perempuan menjadi laki-laki.

Individu-individu yang gelisah ini sedang mengalami dysphoria gender. Dysphoria secara medis didefinisikan sebagai "suatu keadaan emosional yang ditandai dengan kecemasan, depresi, dan kegelisahan."2 American Psychiatric

${ }^{2}$ http://dictionary.reference.com/browse/dys phoria diakses tanggal 14 November 2018. 
Association (APA) menjelaskan bahwa dysphoria gender mengacu pada ketidaknyamanan yang besar dan lama dari seseorang atas ketidaksesuaian antara jenis kelamin biologis dan pengalaman psikologis dan emosional gender. ${ }^{3}$ Sedangkan Rachel Alsop mengatakan bahwa gender merupakan masalah tentang ketidakpastian. Bukan sekedar laki-laki atau perempuan, banyak yang melihat gender sebagai suatu hal yang relatif, atau bahkan sebuah kontinum. Mereka menganggap jenis kelamin atau identitas seks menjadi masalah konsep yang kurang nyata daripada masalah penemuan pribadi. ${ }^{4}$

Selain menghadapi masalah identitas, kaum transgender juga menghadapi berbagai tekanan baik dari sisi psikologis maupun kesehatan. National Center for Transgender Equality telah melakukan survei terhadap 27.715 orang transgender pada tahun 2015 . Dari hasil survei tersebut didapatkan data bahwa: $39 \%$ orang transgender menderita tekanan psikologis serius (dibandingkan dengan 5\% di antara orang Amerika pada umumnya); $40 \%$ orang transgender telah mencoba bunuh diri (dibandingkan dengan 4,6\% di antara orang Amerika pada

\footnotetext{
${ }^{3}$ Mark Yarhouse, "Understanding the Transgender Phenomenon," http://www.christianitytoday.com/ct/ 2015/ julyaugust/ understanding-transgender-genderdysphoria.html? diakses tanggal 14 November 2018.
}

umumnya); $7 \%$ orang transgender telah mencoba bunuh diri pada tahun lalu (dibandingkan dengan 0,6 di antara orang Amerika pada umumnya); 1,4\% dari transgender orang terinfeksi HIV (dibandingkan dengan 0,3\% di antara orang Amerika pada umumnya. ${ }^{5}$

Masalah lain yang timbul terhadap kaum transgender adalah kekerasan fisik hingga pembunuhan. Tanggal 20 November setiap tahunnya diperingati sebagai Hari Transgender Internasional atau International Transgender Day of Remembrance (TDor). Beberapa lainnya menjadikan hari ini sebagai Hari Mengenang Kekerasan dan Diskriminasi terhadap Transgender Sedunia. Tonggak sejarah atas peringatan TDor ini berawal dari dibunuhnya Rita Hester oleh orang tak dikenal pada tanggal 28 November 1998. Rita seorang transgender dan aktivis di San Fransisco, Amerika Serikat. Pembunuhan transgender yang dialami oleh Rita bukan hanya terjadi di Amerika Serikat saja, tetapi juga di Indonesia. Penembakan 3 Waria di Taman Lawang, Jakarta Pusat pada 4 Maret 2011 yang menewaskan satu orang waria bernama Faisal Harahap alias Shakira Lopes. Sampai sekarang pelaku pembunuhan

\footnotetext{
${ }^{4}$ Rachel Alsop, Theorizing Gender: An Introduction (Malden, Massachussetts: Blackwell Publishers, 2002)

${ }^{5}$ S. E. James, J. L. Herman, S. Rankin, M. Keisling, L. Mottet, \& M. Anafi, The Report of the 2015 U.S. Transgender Survey (Washington, DC: National Center for Transgender Equality, 2016).
} 
masih berkeliaran karena belum pernah dihukum. ${ }^{6}$

Pelayanan Kristen bagi kaum transgender harus dimulai dengan menemui mereka di mana mereka berada, mengenal mereka dan memahami cerita mereka. Di luar titik awal itu, para hamba Tuhan harus menjadi orang-orang yang menunjukkan kebenaran dan kasih. Berdasarkan hal-hal tersebut maka penulisan artikel ini bertujuan untuk memberikan pemahaman tentang transgender dalam perspektif Kristen. Penulis berharap artikel ini pada akhirnya dapat berguna bagi pelayanan pastoral care terhadap kaum transgender.

\section{METODE PENELITIAN}

Dalam meneliti artikel ini, penulis menggunakan metode penelitian pendekatan studi literatur.

\section{ANALISIS DAN HASIL PENELITIAN}

\section{$\underline{\text { Definisi Istilah Gender dan Transgender }}$}

Sebelum membahas tentang istilah transgender, perlu dipahami terlebih dahulu apa yang dimaksud dengan gender. Dalam kitab Kejadian 1:27 disebutkan bahwa Allah menciptakan manusia itu laki-laki (bahasa Ibrani: רָָ (zākar) male) dan perempuan

\footnotetext{
${ }^{6}$ http://www.kalyanamitra.or.id/2013/11/tran sgender-masih-menjadi-komunitas-yangtermarjinalkan/ diakses tanggal 14 November 2018.

${ }^{7}$ The Theological Wordbook of the Old Testament, by R. Laird Harris, Gleason L. Archer Jr.,
}

(bahasa Ibrani Allah menciptakan manusia supaya bermultiplikasi. Hal ini nampak dalam kata kerja qal imperatif yang digunakan yaitu פרָ (pārâ) yang artinya "berbuahlah" atau "bear fruit, be fruitful." LAI menerjemahkannya "beranakcuculah" (Kej. 1:28). Ada maksud ilahi saat Allah menciptakan manusia menurut gambar-Nya. Jadi, sejak dari permulaannya manusia diciptakan sebagai pria (he) dan wanita (she) yang memiliki kedudukan yang sama sebagai ahli waris, baik atas citra ilahi maupun atas kekuasaan atas bumi. Pendapat ini didukung oleh William Dyrness, dengan mengatakan: "Laki-laki dan perempuan adalah mahkota ciptaan; mereka diciptakan untuk memerintah."8 Keduanya memiliki perbedaan karakter, secara fisik dan mental terlihat sangat mencolok. Secara fisik lakilaki digambarkan sebagai sosok yang kuat, rasional, gagah, kekar, jantan, perkasa, sedangkan perempuan digambarkan sebagai sosok yang memiliki sifat dan ciri lemah lembut, cantik, emosional, cerewet, keibuan.

Dalam masyarakat sering terjadi ketidakjelasan dan kesalahpahaman tentang istilah gender dan jenis kelamin. Kedua istilah tersebut sebenarnya memiliki

Bruce K. Waltke, originally published by Moody Press of Chicago, Illinois. Copyright (C) 1980.

${ }^{8}$ William Dyrness, Tema-tema dalam Teologi Perjanjian Lama (Malang: Yayasan Penerbit Gandum Mas, 1979), 63. 
perbedaan makna. Dalam Webster's New World Dictionary, gender diartikan sebagai perbedaan yang tampak antara laki-laki dan perempuan dilihat dari segi nilai, tingkah laku, budaya dan psikologi. ${ }^{9}$ Women's Studies Encyclopedia menjelaskan bahwa gender adalah suatu konsep kultural yang berupaya membuat pembedaan (distinction) dalam hal peran, perilaku, mentalitas, dan karakteristik emosional antara laki-laki dan perempuan yang berkembang dalam masyarakat. ${ }^{10}$ Sedangkan Noelen Heyzer memberikan definisi gender sebagai sifat dan perilaku yang dilekatkan pada laki-laki dan perempuan yang dibentuk secara sosial maupun budaya. ${ }^{11}$

Dalam penelitiannya dengan Gerai di Kalimantan, Christine Helliwell menemukan bahwa perempuan dan laki-laki tidak dianggap sebagai sosok manusia yang berbeda dan tidak ada pemahaman dimorfis 'maskulinitas' dan 'feminitas'. ${ }^{12}$ Sebaliknya, Helliwell menulis bahwa laki-laki dan perempuan sebagai sosok yang memiliki bakat dan kecenderungan berperilaku yang sama dengan derajat yang berbeda-beda. Laki-laki dianggap sebagai sosok yang

\footnotetext{
${ }^{9}$ http://www.merriam-

webster.com/dictionary/gender diakses tanggal 14 November 2018.

${ }^{10} \mathrm{http}: / /$ gem.greenwood.com/wse/wseDispla y.jsp?id=id264\&ss=gender diakses tanggal 15 November 2018.

${ }^{11}$ Noelen Heyzer, Daughters in Industry: Work, Skill, and Conscious of Women Workers in Asia
}

pemberani dan memiliki pengetahuan yang lebih banyak tentang hukum lokal, sementara perempuan dianggap lebih ajeg dan memiliki daya tahan. Pembedaan-pembedaan sudah ditentukan bagi perempuan dan laki-laki, namun landasan dimana gender individu ditentukan tidak datang dari karakter tubuh fisik mereka. Melainkan, gender 'dipahami dari kapasitas yang berbeda dalam melakukan kerja-kerja tertentu, kapasitas yang ditentukan jauh sebelum tubuh seseorang terbentuk' ${ }^{13}$

Jika "jenis kelamin" (bahasa Inggris: sex) adalah sesuatu yang dibawa sejak lahir, maka "gender" adalah sesuatu yang dibentuk karena pemahaman yang tumbuh dan berkembang dalam masyarakat. Sebagai contoh, seorang perempuan bertugas membesarkan dan mengasuh anak dan lakilaki bekerja mencari nafkah. Ini adalah pembedaan yang bersifat "gender". Sedangkan pembedaan bahwa laki-laki membuahi dan perempuan yang mengandung, melahirkan, dan menyusui adalah pembagian yang berdasarkan fungsi biologis.

(Kuala Lumpur: Asian and Pacific Development Center, 1988), 14.

${ }^{12}$ Sharyn Graham Davies, Keberagaman Gender di Indonesia (Jakarta: Yayasan Pustaka Obor Indonesia, 2017), 57.

${ }^{13} \mathrm{Ibid}, 58$. 
Gender tidak bisa disebut sebagai kodrat atau ketentuan Tuhan karena gender berkaitan dengan proses keyakinan bagaimana seharusnya laki-laki dan perempuan berperan dan bertindak sesuai dengan tata nilai yang terstruktur, ketentuan sosial dan budaya di tempat mereka berada. Misalnya dalam kehidupan sosial dan budaya, perempuan memiliki peran gender dalam mendidik anak, merawat anak, dan mengelola kebersihan rumah tangga tetapi peran tersebut dapat pula dilakukan oleh lakilaki. Oleh karena itu jenis pekerjaan tersebut dapat dipertukarkan dan tidak bisa bersifat universal. Gender mengacu pada dimensi sosial-budaya seseorang sebagai laki-laki atau perempuan. Salah satu aspek gender melahirkan suatu peran gender (general) yang merupakan suatu harapan yang menetapkan bagaimana seharusnya perempuan dan laki-laki berpikir, bertingkah laku, dan berperasaan.

Istilah kedua yang perlu dipahami ialah transgender. Transgender adalah orang yang berperilaku atau penampilannya tidak sesuai dengan peran gender pada umumnya. Kamus Istilah Kesehatan mendefinisikan transgender sebagai perilaku yang dilakukan

\footnotetext{
${ }^{14} \mathrm{https}: / /$ kamuslengkap.com/kamus/kesehata n/arti-kata/transgender diakses tanggal 15 November 2018.

${ }^{15} \mathrm{http}: / /$ www.e-psikologi.blogspot.com,2006 diakses tanggal 16 November 2018.

${ }^{16}$ Orientasi seksual adalah sebuah preferensi seksual atau pilihan yang menentukan apakah
}

baik oleh laki-laki maupun perempuan yang di luar kodratnya. ${ }^{14}$ Mereka merasa bahwa dirinya bukan merupakan gender yang sekarang membentuk dirinya, sehingga mereka berperilaku dan berpenampilan seperti gender yang mereka inginkan. Transgender adalah orang yang dalam berbagai level "melanggar" norma kultural mengenai bagaimana seharusnya pria dan wanita itu. Seorang wanita, misalnya, secara kultural dituntut untuk lemah lembut. Kalau pria yang berkarakter demikian, itu namanya transgender. Orang-orang yang lahir dengan genitalia luar yang merupakan kombinasi pria-wanita juga termasuk transgender. Transgender ada pula yang mengenakan pakaian lawan jenisnya, baik sesekali maupun rutin. Perilaku transgenderlah, yang mungkin membuat beberapa orang mengganti jenis kelaminnya, seperti pria berganti jenis kelamin menjadi wanita, begitu pula sebaliknya. ${ }^{15}$

Tentunya jika seseorang tergolong transgender, maka ini akan kait mengait dengan orientasi seksualnya ${ }^{16}$ kepada sesama jenis. Yash menyebutkan bahwa seorang transgender dapat saja mengidentifikasikan dirinya sebagai seorang heteroseksual,

seseorang memilih anggota jenis yang sama (homoseksual) atau lawan jenis (heteroseksual), atau keduanya (biseksual) untuk kepuasan seksual. Dikutip dari Kris H. Timotius, Otak dan Perilaku (Yogyakarta: ANDI, 2018), 176. 
homoseksual, atau biseksual. ${ }^{17}$ Menurut diagnosis medis konvensional, transeksualisme adalah salah satu bentuk Gender Dysphoria (kebingungan gender). Gender Dysphoria adalah sebuah term general bagi mereka yang mengalami kebingungan atau ketidaknyamanan tentang gender kelahiran mereka. ${ }^{18}$ Lelaki yang dianggap transgender dipengaruhi oleh jiwanya. Bila jiwanya adalah jiwa wanita maka dia akan bertingkah laku dan bertutur secara feminin, dan bila merasa dia adalah wanita, maka dia akan mencintai lelaki. Pada umumnya mereka yang merasa tidak nyaman dengan gender-kelaminnya akan melakukan operasi ganti kelamin, setelah itu mengganti identitas gender.

Adapun penyebab terjadinya transgender dapat diakibatkan dua faktor, yaitu: a) Faktor bawaan (hormon dan gen). Faktor genetik dan fisiologis adalah faktor yang ada dalam diri individu karena ada masalah antara lain dalam susunan kromosom, ketidakseimbangan hormon, struktur otak, kelainan susunan syaraf otak. b) Faktor lingkungan. Faktor lingkungan di antaranya pendidikan yang salah pada masa

\footnotetext{
${ }^{17}$ Yash, Transseksual: Sebuah Studi Kasus Perkembangan Transseksual Perempuan ke Laki-laki (Semarang: AINI, 2003), 17.

${ }^{18}$ Ibid.

${ }^{19}$ Fitri Meliya Sari, Konstruksi Media terhadap Transgender, Jurnal Professional FIS UNIVED Vol. 3 No. 1 Juni 2016, 28.

${ }^{20}$ Istilah seksual terdiri dari aspek mental, fisik, emosional dan psikologis dalam bentuk fisik. ...
}

kecil dengan membiarkan anak laki-laki berkembang dalam tingkah laku perempuan atau sebaliknya, pada masa pubertas dengan homoseksual yang kecewa dan trauma, trauma pergaulan seks dengan pacar, suami atau istri. ${ }^{19}$

Berdasarkan uraian di atas, maka dapat disimpukan bahwa gender adalah pembedaan peran perempuan dan laki-laki di mana yang membentuk adalah konstruksi sosial dan budaya, jadi bukan karena konstruksi yang dibawa sejak lahir. Sedangkan transgender adalah istilah yang digunakan untuk mendeskripsikan orang yang melakukan, merasa, berpikir atau terlihat berbeda dari jenis kelamin yang ditetapkan saat mereka lahir.

\section{$\underline{\text { Perspektif Kristen tentang Moralitas Seksual }}$}

Menurut pandangan psikoterapis, seseorang yang secara fisik pria, dia tidak harus menerima bahwa ekspresi seksual ${ }^{20}$ alaminya harus tertuju pada wanita. Jika secara fisik wanita, dia tidak harus merasa secara moral terdorong untuk membatasi setiap keinginan seksualnya kepada sesama wanita. Demikian pula, orang yang memiliki

Pengertian tidak terbatas pada masalah reproduksi, regenerasi, perkembangan jenis dalam pengertian biologis dan eksistansi spesiesnya, dan dikatakan umum karena menyangkut banyak hal mengenai proses dan perilaku dalam pergaulan. [Nessi Meilan, Maryanah dan Wila Follona, Kesehatan Reproduksi Remaja: Implementasi PKPR dalam Teman Sebaya (Jakarta: Wineka Media, 2018), 61-62. 
hasrat seksual kepada pria dan wanita, tidak harus berusaha untuk menyangkal keinginan tersebut atau merasa terdorong untuk membatasi kontak seksualnya hanya untuk lawan jenis. Pandangan terakhir psikoterapis yaitu jika hanya karena seseorang memiliki genitalia pria, ia tidak harus didorong untuk mencari pengobatan saat fakta menunjukkan bahwa orang tersebut merasa lebih seperti seorang wanita. ${ }^{21}$

Mayoritas gereja Kristen menentang perubahan perspektif tersebut. Dasar dari perlawanan tersebut justru karena perwujudan manusia dipahami sebagai aspek penciptaan Allah, oleh karena itu instruksi tentang perilaku yang baik dan menyenangkan hati-Nya menjadi syarat yang harus dipenuhi. Perwujudan manusia menunjukkan maksud Allah bagi aktivitas seksual manusia sehingga pria dan wanita dengan menjadi "satu daging" dapat mengakhiri kesendirian mereka dalam kesatuan seumur hidup satu sama lain dan berdasarkan berkat Allah untuk prokreasi anak (Kej. 1:26-28; Kej. 2:18-24). Oleh karena itu keinginan dan aktivitas homoseksual atau biseksual dipandang sebagai bentuk penyimpangan, sebab bertentangan dengan makna dan tujuan

${ }^{21}$ The Lutheran Church -Missouri Synod, Gender Identity Disorder or Gender Dysphoria in Christian Perspective, 2014. perwujudan seseorang sebagai laki-laki atau perempuan.

Firman Tuhan secara tegas melarang bentuk-bentuk penyimpangan seksual dan menyatakannya sebagai kekejian di mata Allah. Dengan kata lain, penyimpangan seksual itu dosa. Orang-orang yang cenderung jatuh dalam dosa ini mereduksinya melalui pernyataan bahwa orientasi seksual mereka berbeda. Beberapa referensi ayat berikut ini kiranya menegaskan batasan yang Allah tetapkan bagi hubungan pria dan wanita:

- Kejadian 19:4-5 “Tetapi sebelum mereka tidur, orang-orang lelaki dari kota Sodom itu, dari yang muda sampai yang tua, bahkan seluruh kota, tidak ada yang terkecuali, datang mengepung rumah itu. Mereka berseru kepada Lot: "Di manakah orang-orang yang datang kepadamu malam ini? Bawalah mereka keluar kepada kami, supaya kami pakai mereka."

- Imamat 18:22 “Janganlah engkau tidur dengan laki-laki secara orang bersetubuh dengan perempuan, karena itu suatu kekejian.”

- Imamat 20:13 "Bila seorang laki-laki tidur dengan laki-laki secara orang 
bersetubuh dengan perempuan, jadi keduanya melakukan suatu kekejian, pastilah mereka dihukum mati dan darah mereka tertimpa kepada mereka sendiri."

- Roma 1:24-27 “Karena itu Allah menyerahkan mereka kepada keinginan hati mereka akan kecemaran, sehingga mereka saling mencemarkan tubuh mereka. Sebab mereka menggantikan kebenaran Allah dengan dusta dan memuja dan menyembah makhluk dengan melupakan Penciptanya yang harus dipuji selama-lamanya, amin. Karena itu Allah menyerahkan mereka kepada hawa nafsu yang memalukan, sebab isteri-isteri mereka menggantikan persetubuhan yang wajar dengan yang tak wajar. Demikian juga suami-suami meninggalkan persetubuhan yang wajar dengan isteri mereka dan menyala-nyala dalam berahi mereka seorang terhadap yang lain, sehingga mereka melakukan kemesuman, lakilaki dengan laki-laki, dan karena itu mereka menerima dalam diri mereka balasan yang setimpal untuk kesesatan mereka."

- 1 Korintus 6:9-10 “Atau tidak tahukah kamu, bahwa orang-orang yang tidak adil tidak akan mendapat bagian dalam Kerajaan Allah? Janganlah sesat! Orang cabul, penyembah berhala, orang berzinah, banci, orang pemburit, pencuri, orang kikir, pemabuk, pemfitnah dan penipu tidak akan mendapat bagian dalam Kerajaan Allah.”

Pandangan Alkitab ini bukannya tidak realistis mengenai sifat manusia dalam dunia yang telah jatuh. Tidak dipungkiri bahwa salah satu hasil dari dosa adalah keinginan dan perilaku menjadi tidak tertib. Ada kemungkinan suami dan istri mengalami hasrat seksual terhadap laki-laki dan perempuan selain pasangan mereka. Alkitab bahkan memberikan fakta bahwa terdapat kasus laki-laki dan perempuan yang memiliki hasrat terhadap individu dari jenis kelamin yang sama. Pemikiran terhadap kasus ini berlaku pula untuk laki-laki yang merasa tidak nyaman terus-menerus dengan kelelakiannya atau untuk orang dengan tubuh perempuan yang percaya bahwa dirinya adalah laki-laki. Satu-satunya cara yang obyektif untuk menentukan siapa yang lakilaki atau perempuan ialah melalui bentuk tubuh manusia itu sendiri. Tuhan memberi identitas kepada manusia baik laki-laki dan perempuan.

Yesus mendasari moralitas seksual tidak hanya dalam kebenaran pewahyuan, tetapi juga dalam kodrat natur penciptaan 
(Mat. 19:1-9). Ketika Yesus mengutuk perceraian, Dia melakukannya karena sejak awal "Sang Pencipta" (NIV; "he who created them") telah menjadikan manusia laki-laki dan perempuan (Mat 19:4). Yesus menunjuk kepada ciptaan manusia sebagai laki-laki dan perempuan dan karena itu mendukung kesimpulan bahwa "seorang laki-laki akan meninggalkan ayah dan ibunya dan bersatu dengan istrinya, sehingga keduanya menjadi satu daging," mengutip Kejadian 2:24. Sebagai satu daging, laki-laki dan perempuan telah dipersatukan oleh Tuhan sehingga tidak boleh berpisah.

Paulus berbicara dalam konteks yang sama antara laki-laki dan perempuan dan bagian dasar yang sama dari Kitab Kejadian dalam ajarannya tentang pernikahan (Ef. 5: 22-33). Dan ketika dia lebih lanjut membahas moralitas seksual dalam kehidupan perkawinan dan bagi yang belum menikah (1 Kor. 6:12-7: 40). Paulus menyatakan dalam perspektif pengakuan atas perwujudan penciptaan manusia sebagai laki-laki dan perempuan ("muliakanlah Allah dengan tubuhmu," 1 Kor. 6:20), harapan pengendalian diri dalam hal seksual apakah menikah atau tidak menikah (1 Kor. 6:18; 7:5,9), panggilan untuk menjalani kehidupan (1 Kor. 7: 17, 24), dan prioritas melayani Tuhan dalam kehidupan sehari-hari (1 Kor. $7: 32)$.
Teologi Kristen secara konsisten telah berusaha untuk membedakan keinginan dan perasaan dari perilaku. Keserakahan, kemarahan, iri hati, dendam, kesombongan, depresi, dan berbagai bentuk nafsu adalah beberapa contoh dari perasaan atau keinginan yang merupakan bagian dari kejatuhan kodrat manusia itu sendiri (Gal. 5:17 dan 1 Yoh. 2:16). Manusia harus menentang dan menahan, bukan untuk memuaskan keinginan secara bebas (Rm. 13:14). Oleh karena itu teologi Kristen telah berusaha untuk membedakan antara "keinginan dan bertindak atas keinginan," dan membedakan antara "dosa perilaku tertentu dan orang berdosa itu sendiri." Dalam kejatuhan manusia, perilaku dapat dibentuk melalui disiplin dalam taraf tertentu, sementara perasaan batin dapat dikontrol oleh manusia itu sendiri.

Kekristenan memahami homoseksualitas, biseksualitas, atau transgender dalam kerangka moral secara komprehensif. Terjadi konflik pemikiran antara penganut kebenaran sebagaimana terungkap dari Alkitab dan dari orang-orang yang mengikuti hukum alam, misalnya dari golongan masyarakat profesional seperti dari psikolog atau psikiatri. Arah Alkitab jelas melarang aktivitas homoseksual, namun tidak ada referensi alkitabiah yang eksplisit berbicara tentang individu transgender. Hanya ada referensi yang mengisyaratkan 
implikasi bagi individu yang merasa tidak nyaman dengan identitas dirinya sebagai laki-laki atau perempuan: "Seorang perempuan janganlah memakai pakaian lakilaki dan seorang laki-laki janganlah mengenakan pakaian perempuan, sebab setiap orang yang melakukan hal ini adalah kekejian bagi TUHAN, Allahmu." (Ul. 22:5).

Bagaimanapun, ini merupakan kecaman keras bagi orang yang mengenakan pakaian dari lawan jenis. Istilah Ibrani תוֹעיָרה (to'evah, "pelanggaran") berbicara tentang apa pun yang bertentangan dengan tatanan ritual atau moral, khususnya (dalam PL) dengan standar ilahi. Berpakaian silang dalam konteks perjanjian ini mungkin ditafsirkan homoseksualitas, ritual pemujaan kesuburan, atau praktik terlarang lainnya. Beberapa orang berpendapat bahwa referensi Perjanjian Lama ini tidak memiliki penerapan Kristen. Pendapat umum ini perlu ditinjau dalam kebenaran Firman Tuhan.

1 Korintus 6:9 secara eksplisit menerapkan "hukum moral" bagi orangorang yang tidak menerapkan kebenaran: Atau tidak tahukah kamu, bahwa orangorang yang tidak adil tidak akan mendapat bagian dalam Kerajaan Allah? Janganlah sesat! Orang cabul (KJV: fornicators, NIV: the sexually immoral), penyembah berhala

\footnotetext{
${ }^{22}$ Keperempuan-perempuanan; bersifat seperti perempuan (Kamus 2.03, Freeware@20062007 http://ebsoft.web.id)
}

(NIV: idolaters), orang berzinah (NIV: adulterers), banci (KJV: effeminate, ${ }^{22} \mathrm{NIV}$ : male prostitutes), orang pemburit (NIV: homosexual offenders, YLT: sodomites). Kata "banci" dalam 1 Korintus 6:9 ini berasal dari kata Yunani $\mu \alpha \lambda \alpha \kappa o \varsigma$ (malakos) dan digunakan dalam banyak tulisan Yunani lainnya pada periode waktu yang berarti "halus" dengan cara mencari kesenangan, tanpa kekuatan atau kendali diri. Kata malakos juga digunakan Yesus dalam Matius 11:8 untuk menjelaskan tentang Yohanes Pembaptis "Atau untuk apakah kamu pergi? Melihat orang yang berpakaian halus (malakos)? Orang yang berpakaian halus itu tempatnya di istana raja." Tentu saja dalam pertanyaan tentang Yohanes ini, Yesus membuat referensi terselubung pada Herodes yang mengenakan jubah halus dan tinggal di istana.

Kata malakos memiliki beberapa sejarah sastra pada zaman Yesus. Sekitar 350 tahun sebelum Yesus, Aristoteles berbicara tentang konsep malakos dalam tulisannya yang berjudul "Nicomacheans Ethics.",23

"of the dispositions describe above, the
deliberate avoidance of pain is rather a kind
of softness (malakia); the deliberate pursuit
of pleasure is profligacy in the strict sense."
"One who is deficient in resistance to pains
that most men withstand with success, is soft
(malakos) or luxurious, for luxury is a kind of
softness (malakia); such a man lets his cloak
trail on the ground to escape the fatigue and
${ }^{23}$ Aristotle, Nicomacheans Ethics, Loeb vol 73, VII vii 7; hlm. 73. 
trouble of lifting it, or feigns sickness, not seeing that to counterfeit misery is to be miserable."

John Humble memberikan argumen bahwa kata malakos di dalam Alkitab tidak dimaksudkan mengacu pada "banci". Uraian Aristoteles menurut Humble lebih menjelaskan tentang makna "banci" (KJV: effeminate). Lebih lanjut ia katakana bahwa seharusnya kata yang digunakan adalah kinaidos, yang merupakan istilah Yunani umum pada masa generasi Paulus, untuk menerjemahkan "pria homoseksual banci." 24

Alasan Alkitab tentang natur seksual manusia tidak dapat disangkal. Selain ayatayat sebelumnya, diskusi Paulus tentang homoseksualitas dalam Surat Roma 1 itu penting. Paulus menganggap tindakan homoseksual dalam konteks tersebut adalah natur dari dosa manusia yaitu berupa penindasan atas kebenaran (Rm. 1:18). Paulus memberikan dua contoh penindasan atas kebenaran. Yang pertama adalah penolakan untuk mengakui kuasa dan natur ilahi yang menyebabkan manusia menyembah makhluk bukan Sang Pencipta (Rm. 1:19-23, 25). Contoh kedua Paulus: karena manusia menyembah penciptaan dan bukan Sang Pencipta, maka manusia tidak menghormati tubuh mereka serta tidak mencari kehendak Sang Pencipta untuk

${ }^{24}$ John Humble, The REAL Meaning of Biblical References to Homosexuality (Tulsa: Better Price Quality Products, 2018). penggunaan yang tepat atas tubuh manusia. Pemahaman Paulus tentang amoralitas aktivitas homoseksual didasarkan pada sifat manusia diciptakan sebagai makhluk seksual dan perwujudan manusia sebagai laki-laki atau perempuan.

Berdasarkan paparan tersebut dapat disimpulkan bahwa Allah murka terhadap segala bentuk kefasikan dan kelaliman manusia termasuk di antaranya perilaku seksual yang menyimpang. Walaupun tidak ada penyebutan secara eksplisit tentang transgender, di beberapa bagian Alkitab menyatakan bahwa manusia mencemarkan tubuhnya sendiri melalui keinginannya yang menyesatkan. Keinginan mengubah genitalia berbeda dari yang telah Allah tetapkan adalah salah satu bentuk kesesatan berpikir dan berperilaku.

\section{Teori Queer}

Teori Queer lahir dari kesadaran bahwa komunitas gay/lesbian termasuk kelompok yang terpinggirkan dari budaya dominan yang dikonstruksi selama berabadabad. Ide yang dilontarkan oleh para tokoh queer adalah pemberontakan atas kekerasan yang diterima oleh kelompok gay, lesbian dan transvestites yang dilecehkan, ditangkap, dan dilecehkan oleh polisi New York pada suatu malam. Tokoh-tokoh yang 
memopulerkan ide teori queer dan yang paling berpengaruh dalam dunia akademik adalah Michael Foucault, Guyle Rubin dan Judith Butler. ${ }^{25}$ Teori queer didasarkan pada gender dan seksualitas. Karena hubungan ini, perdebatan muncul, apakah orientasi seksual adalah alami atau esensial. Teori ini tidak hanya menyangkut gender tetapi juga seks. Queer mengkaji kombinasi dari berbagai kemungkinan dari tampilan gender serta tentang proses yang berfokus pada gerakan yang melampaui ide, ekspresi, hubungan, tempat dan keinginan yang menginovasi berbagai perbedaan cara penjelmaan di dunia sosial. Model queer ini dijadikan kerangka kerja dalam mempelajari isu-isu gender, seksualitas dan bahkan politik. ${ }^{26}$

Saat teori queer menciptakan lebih banyak ruang sosial dan politik untuk menerima variasi gender dan identitas seksual, banyak individu transgender tetap menyatakan ketidakpuasan terhadap asumsi konstruktivis yang murni sosial tentang identitas gender yang melekat dalam teori. Teori tentang identitas gender, peranan gender, dan orientasi seksual dari perspektif individu transgender mungkin merupakan tantangan yang lebih radikal bagi keyakinan heteronomikal tradisional tentang gender. ${ }^{27}$

\footnotetext{
${ }^{25}$ Alfian Rokhmansyah, Pengantar Gender dan Feminisme: Pemahaman Awal Kritik Sastra Feminisme (Yogyakarta: Garudhawaca, 2016), 28.

${ }^{26}$ Ibid., 30.
}

Berbagai dialog telah dilakukan di antara komunitas LGBT, tetapi ada semacam perasaan ketidakyakinan di antara komunitas transgender bahwa komunitas gay atau lesbian tidak sungguh-sungguh memahami tentang natur transgender. Sebagaimana Green katakan:

Many gay people do not understand how gender identity issues are related to sexual orientation. Many gays think that their community is about who they have sex with. They do not think about the violation of gender norms that homosexual expression constitutes in the eyes of heterosexual people. A gay man can be perceived as having more feminine qualities and a lesbian woman can be perceived as having more masculine qualities. Straight people often believe that gay people want to be the opposite sex or they think that crossdressing, transsexualism, and homosexuality mean the same thing. Much of the violence and oppression of transpeople is the perceived link between transness and homosexuality. ${ }^{28}$

Berdasarkan uraian di atas, sudut pandang tentang identitas gender dan orientasi seksual masih menjadi perdebatan di antara kaum LGBT sendiri. Ketidakpuasan kaum transgender bukan hanya tentang keberadaan mereka tetapi juga tentang peranan mereka dalam masyarakat. Di antara mereka juga ada yang berprestasi baik di kancah nasional maupun internasional.

${ }^{27}$ Julie L. Nagoshi, Craig T. Nagoshi, Stephanie Brzuzy, Gender and Sexual Identity: Transcending Feminist and Queer Theory (Arlington: University of Texas, 2014), 74.

${ }^{28}$ Ibid. 
$\underline{\text { Krisis Identitas Kaum Transgender }}$

Transgender dipahami sebagai sekelompok orang yang mengalami transformasi gender. Definisi transgender merujuk pada seseorang yang bertransisi di antara dua orientasi seksual dengan menggunakan hormon seksual atau dengan jalan operasi, memindahkan atau memodifikasi alat genitalnya dan organorgan reproduksinya. ${ }^{29}$ Telah banyak kaum transgender yang mengubah jenis kelaminnya. Berikut ini adalah contoh tiga orang yang mengakui di hadapan publik bahwa mereka telah melakukan operasi alat genitalnya antara lain:

1. Nong Tum. Nong Tum lahir pada 9 Juni 1981 sebagai bayi laki-laki. Awalnya terlahir bernama Parinya Kiatbusaba, namun kini lebih populer sebagai Nong Tum. Ia adalah seorang 'Kathoey' sebutan pelaku transeksual dari pria ke wanita di Thailand. Uniknya, Nong tum saat dulu masih seorang laki-laki, ia adalah petinju Muay Thai sejak kecil. Nong Tum memang sudah menyadari ada yang berbeda dari dirinya, namun karena orangtuanya tidak mengetahuinya, maka ia didaftarkan ke camp tinju.

${ }^{29}$ Azis, Pendidikan Seks Perspektif Terapi Sufistik bagi LGBT, 54.

${ }^{30} \mathrm{http} / / /$ riandaprayoga.blogdetik.com/2014/8 -kasus-transgender-di-indonesia-dan-di-dunia/ diakses tanggal 17 November 2018.
Meski pembawaan Nong Tum lebih feminim, namun ia tergolong petinju yang bebakat. Nong Tum pun akhirnya mengikuti kejuaraan tinju dimulai Februari 1998, setelah memenangi pertandingan di Bangkok Lumpini Boxing Stadium. Media Thailand mulai menyadari bahwa ada petinju yang feminim. Setelah itu Nong tum makin terkenal di media massa. Ia pun akhirnya menjalani operasi ganti kelamin pada 1999, sesaat setelah berhenti menjadi petinju. $^{30}$

2. Dena Rahman. Penyanyi cilik Dena 'Renaldy' Rahman dikenal sebagai Renaldy saat menjadi penyanyi cilik cowok di era awal 90-an. Namun setelah sekian lama tidak terdengar kabarnya. Akhir-akhir ini namanya mulai mencuat lagi setelah isu tentang perubahan jalan hidupnya dalam kasus transgender mulai merebak dan menjadi perbincangan hangat di media maupun dunia maya. Dia merasa dirinya terperangkap di tubuh yang salah. ${ }^{31}$

3. Guinnes World Record beberapa waktu lalu mencatat bahwa

\footnotetext{
${ }^{31}$ Ibid.
} 
pengumuman perubahan nama dan kelamin Bruce Jenner telah berhasil memecahkan rekor. Jenner hanya memerlukan waktu 4 jam untuk mencapai angka 1 juta follower dalam akun Twitter barunya. William Bruce Jenner adalah mantan atlet olimpiade, ayah bagi Kendall dan Kyllie Jenner serta ayah tiri bagi Kim dan Kourtney Kardashian, tengah berada pada titik peralihan serta perubahan diri yang cukup mengejutkan. Jenner secara resmi mengumumkan perubahan nama dan jenis kelaminnya Senin (1/6/2017) lalu dalam wawancara dengan majalah Vanity Fair. Bruce menyebutkan nama barunya adalah Caitlyn Jenner. ${ }^{32}$

Dari problem identitas yang dihadapi kaum transgender, dapat disimpulkan bahwa perasaan ketidaknyamanan gender dapat timbul sedari kecil. Dalam beberapa kasus dijumpai beberapa orang tua yang memaksakan anaknya berpakaian yang tidak sesuai dengan identitas seks anak, misalnya seorang anak laki-laki yang dipaksa memakai rok karena orang tua menginginkan anak perempuan. Hal ini dapat mengakibatkan

\footnotetext{
${ }^{32}$ Andre, "Caitlyn Jenner Pecahkan Rekor Pengikut Twitter Barack Obama," Tabloid Genie, Edisi 41/Tahun XI/11-17 Juni 2015.
}

seorang anak mengalami krisis identitas gender. Prof. Dr. Kris H. Timotius menyatakan bahwa identitas gender mengacu pada seseorang/individu yang melihat dan merasakan dirinya sendiri sebagai gender yang berbeda daripada gender yang disahkan (assigned gender). ${ }^{33}$ Peranan orang tua amatlah penting dalam membentuk identitas gender anak. Anak-anak membutuhkan kasih sayang dan perhatian yang cukup dari orang tua mereka. Pengabaian sekecil apapun akan berakibat fatal bagi masa depan anak-anak.

Permasalahan tidak berhenti di situ. Setelah masuk dalam tahap pemahaman agama dan identitas diri, orang-orang transgender yang dibesarkan di tengah keluarga Kristen pun tidak luput dalam menghadapi dilemma antara memilih keyakinan agama atau mengakui identitas transgender secara terbuka. Yang memilih keyakinan agama berjuang keras untuk menjadi heteroseksual, sedangkan yang memilih mengakui identitas berusaha mengabaikan keyakinan agama yang menurut mereka terlalu menganggap buruk identitas transgender.

Wilcox mencatat sebuah perkembangan yang menakjubkan beberapa dekade ini tentang muncul dan berkembangnya jemaat-jemaat LGBT.

\footnotetext{
${ }^{33}$ Timotius, Otak dan Perilaku, 176.
} 
Beberapa kelompok agama adalah kelompok yang berusaha memberikan dukungan untuk memberikan pelayanan kepada orang-orang transgender yang berusaha kembali pada keyakinan agama. Sedangkan kelompok yang lain mengadakan pelayanan ibadah khusus bagi kaum transgender. ${ }^{34}$ Penelitianpenelitian tentang dilemma antara identitas agama dan identitas gender pun telah banyak dilakukan. Sebuah artikel yang ditulis oleh Scott Thumma berjudul "Negotiating a Religious Identity" membahas tentang krisis identitas yang dihadapi kaum gay dan lesbian dalam tradisi agama konservatif. Thumma mendapati hanya sedikit responden yang mau terlibat dalam pertemuan untuk membahas rekonsiliasi antara identitas gay dan lesbian dengan keyakinan fundamentalis atau Injili mereka. Thumma menyarankan negosiasi untuk sebuah identitas religius baru yang terintegrasi. $^{35}$

\section{Pastoral Care bagi kaum Transgender}

\section{Dalam Counseling Insights: A}

Biblical Perspective on Caring for People seorang pendeta digambarkan sebagai penasihat yang memiliki jiwa gembala.

\footnotetext{
${ }^{34}$ Melissa M. Wilcox, Coming Out in Christianity: Religion, Identity, and Community (Bloomington: Indiana University Press, 2003), 11.

${ }^{35}$ Ibid, 13.

${ }^{36}$ Kelly Arabie, et.al., Insight for Living Counseling Insights: A Biblical Perspective on Caring for People (Plano, TX: Insight for Living, 2007), 5.
}

\begin{abstract}
As a shepherd-counselor, you model God's heart for His sheep. You rescue them from dangerous isolation and tenderly rebuke their resistance to godly obedience. If you already have a relationship apart from this crisis, you may understand their responses and background, perhaps even know their family. Regardless of your relationship, your goal as a biblical counselor is to provide empathetic direction that can help the whole person, not just bandage the crisis. You can corral them into the protective flock of the church body, and encourage them to safe pasture through correction and unconditional love. ${ }^{36}$
\end{abstract}

Seorang pendeta dianggap mampu menasihati mereka yang terluka atau berdosa, dan membawa mereka kembali ke hubungan yang benar dengan Allah. Menurut Hughes, "Ada kecenderungan bagi pendeta untuk mengalihdayakan konseling di gereja lokal kepada konselor profesional yang telah terlatih; namun demikian, orang-orang Kristen dewasa sering kali dapat menghadapi masalah dalam menjalani kehidupan yang telah dijawab oleh Alkitab. Meskipun ada kasus-kasus luar biasa yang mungkin membutuhkan seorang profesional, banyak masalah yang dihadapi orang sering kali dapat diatasi melalui kelompok pendukung awam, seorang mentor, atau pengasuh awam lainnya." 37

Gereja juga perlu memahami setiap anggota jemaatnya melalui pendekatan

\footnotetext{
${ }^{37}$ Ronald Edwin Hughes, Sheperding the Flock: A Model for Pastoral Ministry (Roswell, Georgiay: Liberty University Baptist Theological University, 2015), 9.
} 
keluarga. Analogi tentang gereja yang terdapat dalam Alkitab adalah keluarga. John Bisagno menulis tentang gereja sebagai keluarga yang mendemonstrasikan kasih Kristus dalam tindakan:

We rightfully think of the church as family (Eph. 3:15). Seen in this light, our core values are love and care (1 John 3:11). We give priority to helping those who are physically weak: infants, members in the hospital, and the elderly (1 Tim. 5:8). People expect the church to provide love, security, and a sense of belonging (1 John 3:1). Most people think of the church primarily in these terms. ${ }^{38}$

Keluarga yang sehat memerhatikan setiap anggota keluarganya, termasuk jika salah satu dari anggota keluarga adalah seorang transgender. Tidak semua keluarga dapat menerima kenyataan bahwa salah satu anggota keluarganya adalah seorang transgender. Penolakan dari keluarga dan gereja akan berpengaruh terhadap kejiwaan dan pertumbuhan kerohanian individu transgender.

Para pendeta harus ingat bahwa panggilan mereka bukan hanya untuk melakukan pekerjaan pelayanan mereka sendiri, tetapi juga untuk memerlengkapi atau melatih orang-orang kudus untuk melakukan pekerjaan pelayanan. Anggota jemaat bertanggung jawab untuk menggunakan karunia rohani mereka untuk

${ }^{38}$ John R. Bisagno, Letters to Timothy: A Handbook for Pastors (Nashville, TN: Broadman \& Holman Publishers, 2001), 120. melayani dan merawat orang-orang yang membutuhkan pelayanan. Alkitab penuh dengan perintah untuk saling mengasihi, saling mendoakan, dan saling memberi semangat.

Roy B. Zuck berkomentar bahwa surat-surat Paulus memerintahkan orangorang percaya untuk bersatu bersama berdasarkan hubungan keluarga baru mereka di dalam Kristus. ${ }^{39}$ Berulang kali datang instruksi: menderita bersama (1 Kor. 12:26), bersukacita bersama (Rm. 12:15), membawa beban satu sama lain (Gal. 6:2), memulihkan satu sama lain (Gal. 6:1), saling mendoakan (Rm. 15:30), saling mengajar dan menasihati (Kol. 3:16), saling menyegarkan (Rm. 15:32), saling menyemangati (Rm. 1:12), saling mengampuni lainnya (Ef. 4:32). . dan saling memberi (Flp. 4: 14-15). Penekanan besar dari Surat-surat Perjanjian Baru jelas bahwa orang percaya harus memberi diri mereka dengan murah hati satu sama lain dalam membangun satu sama lain, dalam saling memperhatikan, dalam saling mencintai, dan dalam menjaga perdamaian di antara mereka sendiri. Kaum transgender adalah orang-orang yang memerlukan penerimaan, kasih, perhatian, pengampunan dan pemulihan. Pelibatan anggota keluarga dari individu transgender maupun dari

${ }^{39}$ Roy B. Zuck, Vital Church Issues: Examining Principles and Practices in Church Leadership (Grand Rapids, MI: Kregel Resources, 1998), 50-51. 
relawan yang terpanggil untuk melayani kaum transgender akan sangat membantu pelayanan gereja bagi semua anggota jemaat.

John F. MacArthur, Jr., Richard Mayhue dan Robert L. Thomas juga mengomentari masalah ini. Menurut mereka para pemimpin gereja perlu melibatkan jemaat. Mereka harus membuat pertemuan, acara, kesempatan pelayanan, struktur dan pola sosial sehingga orang Kristen dapat terlibat satu sama lain. Gereja tidak boleh menjadi sebuah teater, ruang kuliah, atau seperti sebuah acara yang dikunjungi para penonton. Alih-alih, gereja harus menjadi sebuah komunitas tempat berbagi kehidupan yang saling memberkati (1 Kor. 12:14-27). ${ }^{40}$ Komunitas Kristen melibatkan kebersamaan, saling mengasihi, dan saling berkomunikasi. Persekutuan mendengarkan orang-orang yang memiliki kekhawatiran, berdoa dengan orang-orang yang memiliki kebutuhan, mengunjungi orang-orang di rumah sakit, duduk bersama di kelas pelajaran Alkitab, bahkan menyanyikan lagu pujian dengan orang-orang yang belum pernah ditemui sebelumnya. Persekutuan juga melibatkan berbagi permintaan doa.

\footnotetext{
${ }^{40}$ John F. MacArthur, Jr., Richard Mayhue dan Robert L. Thomas. Rediscovering Pastoral Ministry: Shaping Contemporary Ministry with Biblical Mandates (Dallas: Word Publishing, 1998), 79.

$\begin{array}{rrrr}{ }^{41} \text { Church of } & \text { Scotland, Diverse } & \text { Gender } \\ \text { Identities } & \text { and } & \text { Pastoral } & \text { Care. }\end{array}$
}

Usaha untuk melakukan pelayanan pastoral terhadap transgender telah dilakukan oleh beberapa gereja di dunia. Gereja Skotlandia telah menerbitkan sebuah laporan berjudul Diverse Gender Identities and Pastoral Care yang dimaksudkan untuk membantu tim pastoralnya untuk mendukung mereka yang ada di komunitas yang mengidentifikasi diri sebagai transgender. ${ }^{41}$ Menumbuhkan kesadaran doktrinal kepada kaum transgender tidaklah semudah membalik telapak tangan. Pendeta memahami bahwa orang yang sedang berjuang dengan identitas seksual (natal sex $)^{42}$ memang berurusan dengan gangguan serius, tapi dia juga akan mengerti bahwa kebutuhan terdalam dari seorang laki-laki atau perempuan seperti itu adalah mengetahui bahwa ia dicintai oleh Allah. Kasih dan pengampunan Kristus merupakan kebutuhan terbesar manusia. Kesedihan, kebingungan, frustrasi, malu, dan putus asa mungkin hadir dalam setiap individu yang berurusan dengan dysphoria gender atau berjuang dengan pertanyaan-pertanyaan tentang identitas dirinya sebagai laki-laki atau perempuan. Jika individu tersebut belum mencari perawatan psikoterapi, pendeta

http://www.churchofscotland. org.uk/resources/learn/publications/diverse_gender_i dentities_and_pastoral_care.

${ }^{42}$ Identitas seksual adalah bagaimana kita mengidentifikasi diri sendiri dan/atau secara umum/public. Dikutip dari Timotius, Otak dan Perilaku, 176. 
harus berusaha untuk mendorong dan mungkin, memfasilitasi individu dalam terapi yang tepat dan tidak bertentangan dengan iman Kristen. Pelayanan pastoral untuk orang yang berjuang dengan identitas seksual tidak dimulai dengan perdebatan tentang moral.

Pendekatan pastoral care yang dianjurkan dapat diringkas dalam satu kata yaitu 'penerimaan'. Setiap orang harus menerima tanpa syarat dan tanpa mempertanyakan identitas yang diklaim oleh orang-orang transgender dan mendukung mereka dalam menjalani identitas-identitas itu. Tindakan menemukan identitas gender yang sebenarnya dapat membantu kesehatan mental mereka, sebaliknya tidak mengakui identitas itu akan merusak mental dan bahkan dapat mengakibatkan bunuh diri. Pemahaman akan teori queer setidaknya akan membantu dalam menyelami pola pikir kaum transgender. Bagaimanapun mereka adalah anggota masyarakat yang tidak dapat dipungkiri keberadaannya.

Pastoral care perlu didasarkan pada pengembangan persahabatan Kristen yang sejati mengikuti model persahabatan yang tidak mengenal batas (Luk. 7:34). Pastoral care yang penuh kasih bagi seorang individu transgender akan berusaha untuk memberikan pemeliharaan, dorongan, dan penerimaan. Pastoral care adalah 'tempat yang aman' secara spiritual kepada seorang transgender yang mungkin menderita pengucilan, ejekan, dan permusuhan yang nyata atau yang dirasakan. Dia mungkin memandang gereja dengan curiga bahwa Kekristenan lebih mementingkan penilaian moral, persaingan budaya, atau kemenangan politik daripada memerhatikan orang-orang yang hancur dan menderita. Saat menerima individu yang berjuang, hubungan kepercayaan antarpribadi berkembang. Di dalam hubungan itu akan ada peluang alami untuk membuat Kristus dikenal, untuk memanggil orang itu untuk percaya pada janji dan kasih-Nya, dan untuk menunjukkan bahwa tujuan dan perintah Allah bagi hidup manusia adalah untuk kebaikan manusia itu sendiri.

Oleh karena jalur pertumbuhan, pengudusan, dan perubahan yang diharapkan bisa saja lambat dan menyakitkan sedangkan pergulatan hidup tak terelakkan, dalam hal ini pastoral care perlu melibatkan kesabaran dan komitmen jangka panjang untuk berdoa, mengasihi, mendengarkan dan membantu orang yang bersangkutan dengan cara apa pun yang diperlukan. Itu juga berarti terus mengasihi dan tetap mendukung kaum transgender bahkan jika kemajuan lambat atau kekambuhan terjadi, percaya bahwa Tuhan sedang memproses dan memiliki kapasitas untuk menghasilkan hasil yang diinginkannya. Seperti yang diingatkan Walt Heyer dalam A Transgender's Faith: "kita 
tidak boleh menyerah pada manusia, tidak peduli berapa kali mereka gagal atau berapa lama pemulihan berlangsung. Kita tidak boleh meremehkan kekuatan penyembuhan dari doa dan kasih di tangan Tuhan. Kita jangan pernah putus asa." 43

\section{KESIMPULAN}

Alkitab berisi petunjuk tentang pentingnya peran hamba Tuhan sebagai gembala. Selain itu, Alkitab mengajarkan bahwa setiap orang percaya harus memainkan peranan penting dalam merawat orang percaya lainnya dan komunitas yang lebih besar. Keduanya dapat dan harus terjadi secara bersamaan di sebuah gereja. Pendeta memiliki peran penting untuk memperlengkapi orang-orang percaya untuk melakukan pelayanan sebagai wujud kasih pada sesama. Selain pelayanan doa dan firman, pendeta penting mendorong orangorang percaya yang dewasa rohani untuk memimpin di banyak bidang pelayanan pastoral di gereja lokal. Alkitab menyediakan kerangka kerja untuk memahami revolusi transgender. Pandangan dunia Kristen yang diinformasikan oleh Alkitab dapat sepenuhnya menjelaskan mengapa orang mengalami disphoria gender. Pandangan dunia Kristen adalah pandangan yang mengakui bahwa ciptaan telah mengalami kerusakan. Tidak ada bagian dari keberadaan manusia di alam semesta ini yang tidak terganggu oleh efek dosa. Ini berarti bahwa kehancuran ciptaan mencapai ke setiap sudut kehidupan manusia. Setiap manusia diciptakan menurut gambar Allah. Dalam derajat dan cara yang berbeda, setiap manusia berjuang dengan kehancuran tubuh, keinginan, dan pikiran manusia itu sendiri. Pada tingkat yang sama, setiap manusia dapat menemukan identitas mereka yang sebenarnya dengan mengakui bahwa Tuhan yang menciptakan mereka juga telah menyelamatkan mereka dan suatu hari akan memulihkan mereka.

\section{DAFTAR PUSTAKA}

$\underline{\text { Buku}}$

Alsop, Rachel. Theorizing Gender: An Introduction. Malden, Massachussetts: Blackwell Publishers, 2002.

Arabie, Kelly et.al., Insight for Living Counseling Insights: A Biblical Perspective on Caring for People. Plano, TX: Insight for Living, 2007.

Azis, Safrudin. Pendidikan Seks Perspektif Terapi Sufistik bagi LGBT. Kendal: Achmad Jaya Group, 2017.

Bisagno, John R. Letters to Timothy: A Handbook for Pastors. Nashville, TN: Broadman \& Holman Publishers, 2001. 
Davies, Sharyn Graham. Keberagaman Gender di Indonesia. Jakarta: Yayasan Pustaka Obor Indonesia, 2017.

Dyrness, William. Tema-tema dalam Teologi Perjanjian Lama. Malang: Yayasan Penerbit Gandum Mas, 1979.

Harris, R. Laird, Gleason L. Archer Jr., Bruce K. Waltke. The Theological Wordbook of the Old Testament, by, originally published by Moody Press of Chicago, Illinois. Copyright (C) 1980.

Heyzer, Noelen. Daughters in Industry: Work, Skill, and Conscious of Women Workers in Asia. Kuala Lumpur: Asian and Pacific Development Center, 1988.

Hughes, Ronald Edwin. Sheperding the Flock: A Model for Pastoral Ministry. Roswell, Georgiay: Liberty University Baptist Theological University, 2015.

Humble, John. The REAL Meaning of Biblical References to Homosexuality. Tulsa: Better Price Quality Products, 2018.

James, S. E., J. L. Herman, S. Rankin, M. Keisling, L. Mottet, \& M. Anafi, The Report of the 2015 U.S. Transgender Survey. Washington, DC: National Center for Transgender Equality, 2016.

John F. MacArthur, Jr., Richard Mayhue dan Robert L. Thomas. Rediscovering Pastoral Ministry: Shaping Contemporary Ministry with Biblical Mandates. Dallas: Word Publishing, 1998

Meilan, Nessi, Maryanah dan Wila Follona, Kesehatan Reproduksi Remaja:
Implementasi PKPR dalam Teman Sebaya. Jakarta: Wineka Media, 2018.

Nagoshi, Julie L., Craig T. Nagoshi, Stephanie Brzuzy, Gender and Sexual Identity: Transcending Feminist and Queer Theory. Arlington: University of Texas, 2014.

Rokhmansyah, Alfian. Pengantar Gender dan Feminisme: Pemahaman Awal Kritik Sastra Feminisme. Yogyakarta: Garudhawaca, 2016.

The Evangelical Alliance, Transsexuality. Carlisle: Paternoster Press, 2000.

Timotius, Kris H. Otak dan Perilaku. Yogyakarta: ANDI, 2018.

Wilcox, Melissa M. Coming Out in Christianity: Religion, Identity, and Community. Bloomington: Indiana University Press, 2003.

Yash, Transseksual: Sebuah Studi Kasus Perkembangan Transseksual Perempuan ke Laki-laki. Semarang: AINI, 2003.

Zuck, Roy B. Vital Church Issues: Examining Principles and Practices in Church Leadership. Grand Rapids, MI: Kregel Resources, 1998.

\section{$\underline{\text { Jurnal }}$}

Sari, Fitri Meliya. "Konstruksi Media terhadap Transgender," Jurnal Professional FIS UNIVED Vol. 3 No. 1 Juni 2016, 28.

$\underline{\text { Tabloid }}$

Andre, "Caitlyn Jenner Pecahkan Rekor Pengikut Twitter Barack Obama," 
Tabloid Genie, Edisi 41/Tahun XI/11-17 Juni 2015.

\section{$\underline{\text { Internet }}$}

Church of Scotland, Diverse Gender Identities and Pastoral Care. http://www.churchofscotland. org.uk/resources/learn/publications/d iverse_gender_identities_and_pastor al_care.

http://dictionary.reference.com/browse/dysp horia diakses tanggal 14 November 2018.

http://gem.greenwood.com/wse/wseDisplay. jsp?id=id264\&ss=gender diakses tanggal 15 November 2018.

http://riandaprayoga.blogdetik.com/2014/8kasus-transgender-di-indonesia-dandi-dunia/ diakses tanggal 17 November 2018.

http://www.e-psikologi.blogspot.com,2006 diakses tanggal 16 November 2018.

http://www.kalyanamitra.or.id/2013/11/trans gender-masih-menjadi-komunitasyang-termarjinalkan/diakses tanggal 14 November 2018.

http://www.merriamwebster.com/dictionary/gender diakses tanggal 14 November 2018.

https://kamuslengkap.com/kamus/kesehatan/ arti-kata/transgender diakses tanggal 15 November 2018.

Yarhouse, Mark. "Understanding the Transgender Phenomenon," http://www.christianitytoday. com/ct/ 2015/ july-august/ understandingtransgender-gender-dysphoria.html? diakses tanggal 14 November 2018. 